\title{
Etiology of UTI - pathogens involved and their sensitivity to antibiotics
}

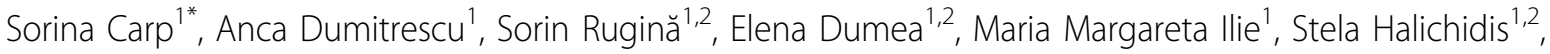 \\ Simona Claudia Cambrea ${ }^{1,2}$ \\ From The 10th Edition of the Scientific Days of the National Institute for Infectious Diseases "Prof Dr Matei Bals" \\ Bucharest, Romania. 15-17 October 2014
}

\section{Background}

The study aims to evaluate the etiologic spectrum of urinary tract infections (UTI) and antibiotic sensitivity of isolates.

\section{Methods}

At the Infectious Disease Hospital in Constanța, between January 2014 and June 2014, urine cultures were performed in patients presenting urinary tract infections. Urine was seeded by loops calibrated technique on Columbia agar with 5\% sheep blood and Drigalski agar. To identify the germs we used latex agglutination kits for Gram-positive germs and API galleries (BioMerieux) for Gram-negative bacilli. Antibiotics susceptibility testing was performed with the help of Kirby-Bauer disc diffusion method.

\section{Results}

Out of the total 805 urine samples performed, 160 turned out positive, isolating in 94 cases (58.7\%) Escherichia coli, 25 cases (15.6\%) Klebsiella spp., 12 cases (7\%) Proteus spp., 15 cases (9.3\%) Enterococcus spp., 7 cases (4.3\%) Staphylococcus spp. and others -7 cases (4.3\%). E. coli was the most common etiological agent of UTI in women ( $64 \%$ of positive cases), men ( $42.3 \%$ of positive cases) and children (47\% of positive cases).

Most of the isolated germs were highly susceptible to imipenem (94.4\%) and fosfomycin (82.28\%). Also, a good sensitivity to ceftriaxone $(69.2 \%)$, quinolones $(71.4 \%)$ and gentamicin (68.68\%) was recorded. In addition, $56.6 \%$ of germs were sensitive to nalidixic acid and $56.6 \%$ to biseptol. We also noticed low sensitivity of germs to amoxicillin/clavulanic acid $-32.7 \%$.

\footnotetext{
* Correspondence: cdaliasorina@yahoo.com

${ }^{1}$ Clinical Infectious Diseases Hospital of Constanța, Romania

Full list of author information is available at the end of the article
}

\section{Conclusion}

Escherichia coli was found in the highest percentage in urinary isolates, predominantly in women. There is an increased sensitivity of strains involved in urinary tract infections to fosfomycin - an affordable antibiotic that can be used in the treatment of these cases.

\section{Authors' details \\ ${ }^{1}$ Clinical Infectious Diseases Hospital of Constanța, Romania. ${ }^{2}$ Faculty of Medicine, "Ovidius" University, Constanța, Romania.}

Published: 15 October 2014

doi:10.1186/1471-2334-14-S7-P33

Cite this article as: Carp et al.: Etiology of UTI - pathogens involved and their sensitivity to antibiotics. BMC Infectious Diseases 2014 14(Suppl 7):P33.
Submit your next manuscript to BioMed Central and take full advantage of:

- Convenient online submission

- Thorough peer review

- No space constraints or color figure charges

- Immediate publication on acceptance

- Inclusion in PubMed, CAS, Scopus and Google Scholar

- Research which is freely available for redistribution

Submit your manuscript at www.biomedcentral.com/submit
() Biomed Central 